American Journal of Agricultural and Biological Sciences 7 (1): 82-87, 2012

ISSN 1557-4989

(C) 2012 Science Publications

\title{
Zinc Phosphide Induced DNA Damage in the Blood Cells of Gallus sp. using Comet DNA Assay
}

\author{
Muid, K.A., R.M. Shahjahan, R. Begum and R.A. Begum \\ Department of Zoology, Faculty of Biological Science, \\ Genetics and Molecular Biology, University of Dhaka, Bangladesh
}

\begin{abstract}
Problem statement: The comet DNA assay is considered a suitable and rapid test for DNAdamaging potential in environmental and biomonitoring studies. Approach: During the study comets were analyzed as a measure of DNA damage to quantify the damage in the blood cells of fowls (Gallus sp.) after exposure to Zinc Phosphide $\left(\mathrm{Zn}_{3} \mathrm{P}_{2}\right)$. Here the potential for DNA strand breaks by $\mathrm{Zn}_{3} \mathrm{P}_{2}$ were considered as biomarker of genotoxicity. Both "in vivo" and "in vitro" experiments were performed to evaluate the DNA damage. Results: Data also revealed that the amount of DNA damage (calculated as damage score) for different doses, had a significant difference with each other. And the genetic toxicity appeared to be dose specific and dose dependent. DNA damage was also found to be positively correlated with period of exposure for a given dose. Conclusion/Recommendations: Thus this study suggested that Zinc Phosphide is toxic to blood nuclear DNA.
\end{abstract}

Key words: Comet DNA assay, Zinc Phosphide $\left(\mathrm{Zn}_{3} \mathrm{P}_{2}\right)$, biomonitoring studies DNA damage and Gallus gallus, Gallus sp, genotoxicity

\section{INTRODUCTION}

Several chemicals find their way into the environment and pose health risk to animal kingdom. These chemicals have been found to interact with the vital tissue macromolecules regulating the cellular functions leading to long lasting health disorders. Acute and chronic exposure to several of these environmental chemicals such as pesticide metals, Polycyclic Aromatic Hydrocarbons (PAHs) solvents have been shown to produce marked toxicity at the target sites. Some of these chemicals affect the DNA. Hence there is a need to test the chemicals for their genotoxic potential before being released into the environment. The conventional methods for evaluating genetic damage include chromosomal aberration, micronucleus assay, sister chromatid exchanges. These techniques are time consuming, resource intensive and require proliferating cell population. Newer and more sensitive test systems have now been introduced for assessing the genotoxicity of chemicals such as comet DNA assay.

The single cell gel electrophoresis or comet assay is a technique for quantitating DNA damage and repair in vivo and in vitro in a eukaryotic cell and some prokaryotic cells. This technique is rapid, non-invasive, sensitive, visual and inexpensive as compared to the conventional techniques. It is a powerful tool to study the factors modifying mutagenicity, carcinogenicity and has rapidly gained importance in the fields of genetic toxicology and biomonitoring (Collins, 2004). Swedish researchers Ostling and Johansson (1984) developed this technique in Singh et al. (1988) later modified this technique, in 1988, as the Alkaline Comet Assay. The resulting image that is obtained resembles a "comet" with a distinct head and tail. The head is composed of intact DNA, while the tail consists of damaged (singlestrand or double-strand breaks) or broken pieces of DNA. The Comet Assay can be used to detect DNA damage caused by double strand breaks, single strand breaks, alkali labile sites, oxidative base damage and DNA cross-linking with DNA or protein. The Comet Assay is also used to monitor DNA repair and nutritional toxicology (Rojas et al., 1999).

Zinc Phosphide $\left(\mathrm{Zn}_{3} \mathrm{P}_{2}\right)$ is an inorganic chemical compound $(75 \%$ of zinc Phosphide and $25 \%$ of antimony potassium tart rate) which is generally used as rodenticides. Zinc Phosphide $\left(\mathrm{Zn}_{3} \mathrm{P}_{2}\right)$ is a heavy, finely ground, crystalline gray-black powder that is practically insoluble in water and alcohol. It was first synthesized in 1740 and was first used as a rodenticide in 1911-12 by the Italians.

All species of animals are subject to zinc Phosphide poisoning, but avian species, specifically gallinaceous birds, are the most seriously affected. In

Corresponding Author: Muid, K.A., Department of Zoology, Faculty of Biological Science, Genetics and Molecular Biology, University of Dhaka, Bangladesh 
Michigan, wild turkeys, ring-necked pheasants, black and gray squirrels, Canada geese and possibly whitetailed deer have died from zinc Phosphide poisoning (Lide, 2004).

DNA damage is an error in DNA. If a cell retains DNA damage replication, transcription and translation of a gene can be blocked and the cell may die. On the other hand DNA repair refers to a collection of processes by which a cell identifies and corrects damage to the DNA molecules that encode its genome. The DNA repair process is constantly active as it responds to damage in the DNA structure. When normal repair processes fail and when cellular apoptosis does not occur, irreparable DNA damage may occur, including double-strand breaks and DNA cross linkages (Bjorksten et al., 1971).

The present study was investigated to assess the Zinc Phosphide $\left(\mathrm{Zn}_{3} \mathrm{P}_{2}\right)$ as a toxicant and to observe its effect on blood nuclear DNA in terms of in vivo and in vitro evaluation.

\section{MATERIALS AND METHODS}

Sample collection and preparation: For in vivo experiment, ten specimens of Gallus sp. commonly known as fowls were collected from Buet bazar, Dhaka, Bangladesh. These were then divided into two groups, treated and non-treated. Among the specimens five were considered as treated and the other five were considered as non-treated group. Then these two groups are kept in separate chambers and they were not fed prior to experiment. Zinc Phosphide was used as treatment dose. The treated group received $0.5 \mathrm{gm}^{-1}$ $\mathrm{mL}$ dose mixed feed through ingestion. The blood sample was collected from treated and non-treated fowl after 12 hours from the ingestion of dose and then comet DNA assay was performed directly.

For in vitro experiment, blood samples were collected from the healthy fowl of Anonda bazaar, Dhaka, Bangladesh. Four doses respectively- 0.05, $0.1,0.2$ and $0.5 \mathrm{gm}^{-1} \mathrm{~mL}$ Zinc Phosphide were prepared and kept in separate eppendorf tubes. One distinct eppendrof containing fresh blood sample leads the control group. For each dose, the observation hours were $2,4,6,8,10,12$ and $24 \mathrm{~h}$ respectively. During this time the samples were placed in the incubator at $37^{\circ} \mathrm{C}$. The comet DNA assay was undertaken according to Singh et al. (1988) and Villela et al. (2006).

Preparation of slides for the comet DNA assay: 01\% (500 mg per $50 \mathrm{~mL}$ PBS) and $0.5 \%$ Low Melting Point Agarose (LMPA) (250 mg per $50 \mathrm{~mL}$ PBS) and $1.0 \%$
Normal Melting Agarose (NMA) (500 mg per $50 \mathrm{~mL}$ in distilled water) were prepared. These were microwaved or heated until near boiling and the agarose dissolved. While NMA was hot, slides were dipped up to one-third the frosted area. Then the slides were air dried and stored at room temperature until needed. Generally the slides were prepared the day before use.

Cell isolation/treatment: From each eppendr of, $5 \mu \mathrm{L}$ of the blood sample were diluted in $1000 \mu \mathrm{L}$ of PBS. 10 $\mu 1$ of cell suspension with $120 \mu \mathrm{L}$ of $0.5 \%$ low melting point agarose at $37^{\circ} \mathrm{C}$, were layered on previously prepared slides, cover-slipped and placed in the refrigerator for $5 \mathrm{~min}$, for solidification of the gel.

Lysis: The cover-slips were then removed and the slides immersed in a freshly prepared lysis solution (1 $\mathrm{mL}$ of Triton-X 100, $20 \mathrm{~mL}$ of DMSO and $79 \mathrm{~mL}$ of lysis stock solution: $25 \mathrm{M} \mathrm{NaCl}, 100 \mathrm{mM}$ EDTA and $10 \mathrm{mM}$ Tris, Ph10.0-10.5) for a minimum of at least 1 $\mathrm{h}$ and a maximum of two, at $4^{\circ} \mathrm{C}$.

Unwinding of DNA: After at least $2 \mathrm{~h}$ at $\sim 4^{\circ} \mathrm{C}$, slides were removed gently from the lysing Solution. Then the slides were placed side by side on the horizontal gel box near one end, as close together as possible. The buffer reservoirs were filled with freshly made electrophoresis buffer $\left(300 \mathrm{mM} \mathrm{NaOH}{ }^{-1} \mathrm{mM}\right.$ EDTA $\mathrm{pH}>13$ ) until the liquid level completely covered the slides. The slides were taken in the alkaline buffer for 20 min to allow for unwinding of the DNA and the expression of alkali-labile damage.

Electrophoresis of microgel slides: Power supply was turn on to 24 volts and 300 milliamperes by raising or lowering the buffer level. The slides were then electrophoresed using agarose gel electrophoresis unit for $30 \mathrm{~min}$. After electrophoresis the power was turned off. The slides were lifted gently from the buffer and place on a drain tray.

Neutralization: Then the slides were coated drop wise with Neutralization Buffer: (0.4 M Tris was added to $\sim 800 \mathrm{~mL} \mathrm{dH} 2 \mathrm{O}$ and $\mathrm{pH}$ was adjusted to 7.5 with concentrated $(>10 \mathrm{M}) \mathrm{HCl}$ : q.s. to $1000 \mathrm{~mL}$ with $\mathrm{dH} 2 \mathrm{O}$ ) for at least $5 \mathrm{~min}$ and repeated twice.

Staining: Then slides were stained with $80 \mu \mathrm{L} 1 \mathrm{X}$ Ethidium Bromide (EtBr; 10X Stock - $20 \mu \mathrm{g} \mathrm{mL}^{-1}$ ) for $5 \mathrm{~min}$ and then dipped in chilled distilled water to remove excess stain. The cover slip was then placed over it and the slides were scored immediately. 
Evaluation of DNA damage: For visualization of DNA damage, observations were made of EtBrstained DNA using $20 \times$ objective on a fluorescent microscope.100 randomly selected nucleoids were analyzed per slide.

Statistical analysis: Statistical analysis was performed using Kruskal-Wallis Test with the level of significance set as $\mathrm{p}<0.05$, utilizing SPSS software.

\section{RESULTS AND DISCUSSION}

Both for in vivo and in vitro experiment, the damaged nucleoids in the treated sample showed comet like fashion with a typical head and tail structure due to the DNA strand breakage where as the undamaged nucleoids were expressed as dot like view (Fig. 1).

One hundred nucleoids per slide were analyzed for every selected hour using visual classification based on the migration of DNA fragments of the nucleus. Comets were classified into four classes: Class $0=$ No damage, Class $1=$ little damage, Class $2=$ Medium damage and Class $3=$ Extensive damage/High damage (Table 1).

Data were presented as the frequency of damaged cells, class distribution and damage scores. The damage score was calculated as the sum of cells in each class and the total number of cells in each class multiplied by the number of classes (0-3). Scores range from zero (all cells with no damage$0 \times 100$ ) to 300 (all cells with maximum damage $3 \times 100$ ), Rigonato et al. (2005) (Table 1).

Within the last decade, the comet DNA assay has been used with increasing popularity to investigate the level of DNA damage in terms of strand breaks and alkaline labile sites in biomonitoring studies. According to Collins (2004), the assay has applications in testing novel chemicals for genotoxicity, monitoring environmental contamination with genotoxins, human biomonitoring and molecular epidemiology and fundamental research in DNA damage and repair.

In the present investigation this technique was tested to observe the effect of Zinc phosphide (rodenticide) on nuclear genome of blood cells of fowl. Belpaeme et al. (1998) stated that the comet assay can also be used to complement studies of chromosome aberrations, micronuclei and sister chromatid exchanges.

Both in vivo and in vitro experiment for comet DNA assay were performed during this investigation. (Mitchelmore and Chipman, 1998) also found a range of genotoxic chemicals, with and without the requirement for metabolic activation give positive effects in various cell types of vertebrate and invertebrate aquatic species, following in vitro and in vivo exposures under laboratory condition.

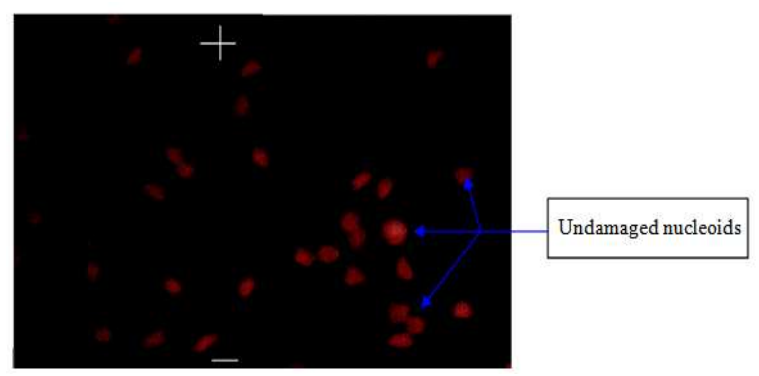

(a)

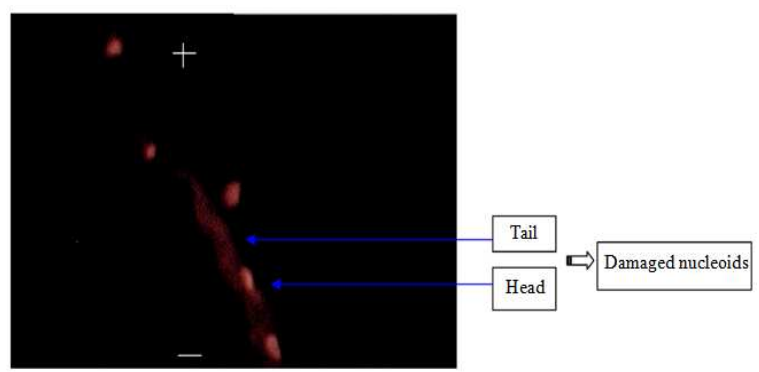

(b)

Fig. 1:Representative fluorescence microscopic observation (200x magnification) of a comet DNA assay showing the DNA migration pattern from non-treated (A) and Zinc Phosphide induced DNA damage with distinct head and tail in the blood cells of Gallus sp. (B). The symboland + represents cathode and anode respectively during electrophoresis. Arrows indicates the dot like view of undamaged nucleoids, head and tail of damaged nucleoids

The comet assay has been successfully applied in erythrocytes of several fish species, thereby showing the sensitivity of the blood cells of these animals to genotoxic effects (Padrangi et al., 1995).

Similarly, in the present experiment blood cells were considered as "Sample". Because in most cases, erythrocytes have been used as target-cells, as they require small volumes that can be obtained through a non-damaging technique and cell dissociation is not needed (Belpaeme et al., 1998).

Souza and Fontanetti (2007) used erythrocytes of Oreochromis niloticus for the comet assay to detect possible genotoxicants in the waters of the Paraíba do Sul River in an area affected by an oil refinery. Cintya et al. (2009) also suggested that erythrocytes of $O$. niloticus are good genotoxicity indicators through the comet assay, an efficient, fast and sensitive method to detect DNA damage. 
Am. J. Agri. \& Biol. Sci., 7 (1): 82-87, 2012

Table 1: In vitro DNA damage analysis

\begin{tabular}{|c|c|c|c|c|c|c|c|c|}
\hline \multirow[b]{2}{*}{$\begin{array}{l}\text { Doses } \\
\mathrm{gm} / \mathrm{mL}\end{array}$} & \multirow[b]{2}{*}{$\begin{array}{l}\text { NA* } \\
\text { perslide }\end{array}$} & \multirow{2}{*}{$\begin{array}{l}\text { Total NA* } \\
\text { (in observation } \\
\text { hours) }\end{array}$} & \multirow[b]{2}{*}{$\begin{array}{l}\text { Comets } \\
(\%)\end{array}$} & \multicolumn{4}{|c|}{ Comet classes } & \multirow[b]{2}{*}{$\begin{array}{l}\text { Damage } \\
\text { score }\end{array}$} \\
\hline & & & & -------------- & 1 & 2 & ------ & \\
\hline 0.05 & 100 & 700 & $14.4 \pm 10.04$ & $85.5 \pm 10.04$ & $10.2 \pm 8.9$ & $3.0 \pm 0.81$ & $1.6 \pm 0.54$ & $19.8 \pm 12.15$ \\
\hline 0.1 & 100 & 700 & $30.8 \pm 13.05$ & $69.1 \pm 13.0$ & $21.2 \pm 7.25$ & $6.5 \pm 4.50$ & $3.5 \pm 3.39$ & $43.4 \pm 22.11$ \\
\hline 0.2 & 100 & 700 & $41.7 \pm 19.50$ & $58.2 \pm 19.5$ & $21.2 \pm 3.9$ & $12.5 \pm 9.5$ & $9.16 \pm 7.4$ & $70.0 \pm 43.87$ \\
\hline 0.5 & 100 & 700 & $51.0 \pm 17.78$ & $49.0 \pm 17.7$ & $24.0 \pm 5.13$ & $14.5 \pm 7.7$ & $12.4 \pm 9.81$ & $90.4 \pm 44.03$ \\
\hline
\end{tabular}

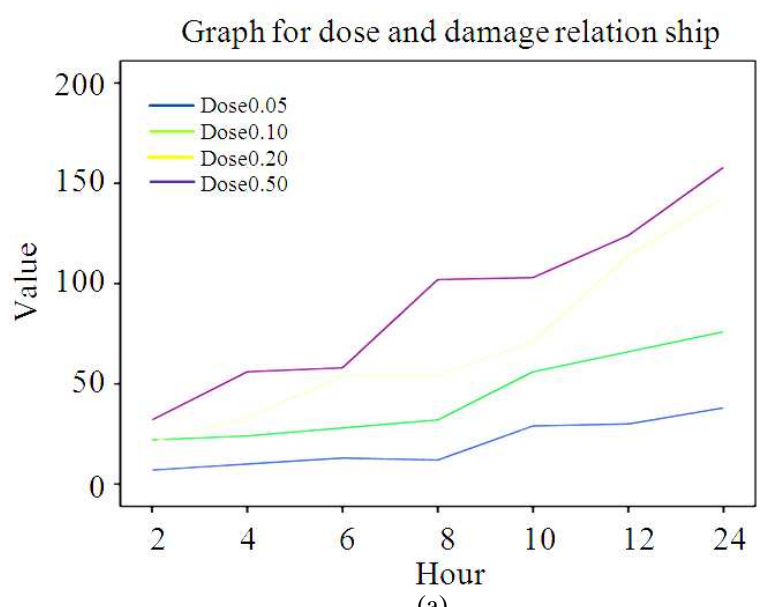

(a)

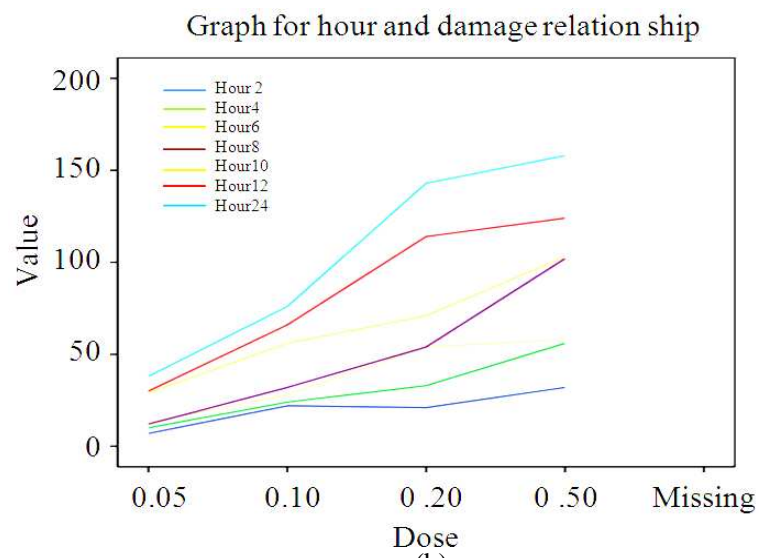

(b)

Fig. 2:(a-b) Graph for hour and dose specific in vitro DNA damage (scored as value)

Table 2: In vitro DNA damage (based on score) and its relationship with doses and hours

\begin{tabular}{|c|c|c|c|c|c|}
\hline \multirow[b]{2}{*}{ Hour } & & \multicolumn{4}{|c|}{ Doses $(\mathrm{gm} / \mathrm{mL})$} \\
\hline & & $0.05 \mathrm{gm} \mathrm{mL}^{-1}$ & ${ }^{1} 0.1 \mathrm{gm} \mathrm{mL}^{-1}$ & $0.2 \mathrm{gm} \mathrm{mL}^{-1}$ & $0.5 \mathrm{gm} \mathrm{mL}^{-1}$ \\
\hline 2 & Damage score & $07 \pm .81 .0$ & $22.2 \pm 1.7$ & $21 \pm 1.20$ & $32.1 \pm 1.6$ \\
\hline 4 & Damage score & $10.5 \pm 1.2$ & $24.1 \pm 2.8$ & $33.2 \pm 1.5$ & $56.2 \pm 1.2$ \\
\hline 6 & Damage score & $13 \pm 1.6 .0$ & $28 \pm 1.6 .0$ & $54.1 \pm .80$ & $58.2 \pm 1.4$ \\
\hline 8 & Damage score & $12.7 \pm 1.7$ & $32 \pm 1.8 .0$ & $54 \pm 1.60$ & $102 \pm 3.20$ \\
\hline 10 & Damage score & $29.2 \pm 1.2$ & $56.2 \pm 1.2$ & $71.4 \pm 2.4$ & $103.2 \pm 1.8$ \\
\hline 12 & Damage score & $30.1 \pm 1.8$ & $66.8 \pm 2.7$ & $114 \pm 4.40$ & $124.4 \pm 2.2$ \\
\hline 24 & Damage score & $38.2 \pm .90$ & $76.1 \pm .77$ & $143.1 \pm 3.2$ & $158 \pm 3.70$ \\
\hline
\end{tabular}

According to Moller et al. (2000) the assay is easily performed on blood cells and has been included in a wide range of biomonitoring studies of occupational exposures encompassing styrene, vinyl chloride, 1,3-butadiene, pesticides, hair dyes, antineoplastic agents, organic solvents, sewage and waste materials, wood dust and ionizing radiation.

But in this experiment, Zinc phosphide was used as "treatment dose and it was observed that this chemical has effect on the blood nuclear DNA (Fig. 1 and Table 1). Similarly, Cintya et al. (2009) also applied Cyclophosphamide (insecticide) to erythrocytes of Oreochromis niloticus for comet DNA assay.

In the present experiment it was clearly distinct that the high or extensive breakage of DNA was observed in a large amount having spreaded long tail when the sample (bloods of fowl) was treated with increased dose ( $0.5 \mathrm{~g}$ Zinc Phosphide per $\mathrm{ml}$ blood) and kept for long time (Fig. 1 and 2). Similar result was found in case of spermatozoa, where high levels of DNA strand breaks showed increased comet tail (Fraser and Strzez, 2004). Irvine et al. (2000) found correlation between poor semen quality and higher levels of damaged DNA detected as DNA fragmentation using the comet assay.

Data also revealed that the amount of DNA damage (calculated as damage score) for all doses has significant differences with each other; hence the genetic toxicity is totally dose dependent and dose specific (Table 2 and Fig. 2). Time (hour) wise variation in the DNA breakage was also detected in this study. It is observed that damage scores have a relationship with doses and period of exposure (hours) and score increased with the increasing amount of dose and hour (Table 2 and Fig. 2). Thus this study suggested that Zinc Phosphide is toxic to blood nuclear DNA.

\section{CONCLUSION}

Zinc Phosphide is well known as rodenticide. It has extensive use to control pest including rodents. This chemical is mixed with feed or water and kept 
near the seed, grain, fruits or crops storage house as a trap. Sometimes unexpected organism like fowls and other useful animals ingest those dose mixed feed and die. However, some can survive due to ingestion of low quantity. But these small doses are able to cause environmental hazards through the biomagnification in the food chain.

It is of public interest that hazardous chemicals should remove from the environment as soon as possible. Consequently, there is a need for rapid and reliable tests that detect DNA damage of agents in different exposure circumstances. The comet assay seems to satisfy many of these criteria. It is fast, inexpensive and requires little biological material (one drop of blood is enough for a measurement). This has made the comet assay increasingly popular during the last 10 years.

In this investigation, comets were analyzed as a measure of DNA damage to quantify the damage and repair in the blood cells of fowl, influenced by Zinc Phosphide. Zinc Phosphide was found to be toxic to blood nuclear DNA and this toxicity increased with the increasing amount of dose. These DNA damages may trigger genomic instability, a crucial step in carcinogenesis.

So the chemical, Zinphosphide, has instant benefit only to control pests but indirectly it acts like a silent killer which may destroys the nuclear DNA of the blood cells of fowls including other animals in the environment.

\section{ACKNOWLEDGEMENT}

The researchers are thankful to Professor Dr. Yasmin of the laboratory of virology, department of Microbiology, P.G hospital and medical college institute, Dhaka, Bangladesh for technical support.

\section{REFERENCES}

Belpaeme, K., K. Cooreman and M.K. Volders, 1998. Development and validation of the in vivo alkaline comet assay for detecting genomic damage in marine flatfish. Mutat. Res. Genet. Toxicol. Environ. Mutagen., 415: 167-184. DOI: 10.1016/S1383-5718(98)00062-X

Bjorksten, J., P.V.N Acharya, S. Ashman and D.B. Wetlaufer, 1971. Gerogenic fractions in the tritiated rat. J. Am. Geriatr. Soc., 7: 561-574. PMID: 5106728

Cintya, A.C., J.A.O. David and C.S. Fontanetti, 2009. Application of the comet assay in erythrocytes of Oreochromis niloticus (Pisces): A methodological comparison. Genet. Mol. Biol., 32: 155-158. 10.1590/S1415-47572009005000020
Collins, A.R., 2004. The comet assay for DNA damage and repair. Mol. Biotech., 26: 249-261. DOI: 10.1385/MB:26:3:249

Fraser, L. and J. Strzez, 2004. The use of comet assay to assess DNA integrity of boar spermatozoa following liquid preservation at 5 and $16^{\circ} \mathrm{C}$. Folia Histochem. Cytobiol., 42: 49-55. PMID: 15046401

Irvine, D.S., J.P. Twigg, E.L. Gordon and R.J. Aitken, 2000. DNA integrity in human spermatozoa: relationships with semen quality. J. Androl., 21: 3344. PMID: 10670517

Lide, D.R., 2004. CRC Handbook of Chemistry and Physics: A Ready-Reference Book of Chemical and Physical Dat. 85th Edn., CRC Press, Boca Raton, FL., ISBN: 0849304857, pp: 2712.

Mitchelmore, C.L and Chipman, 1998. DNA strand breakage in aquatic organisms and the potential value of the comet assay in environmental monitoring. Mutat., Res., 399: 135-147. PMID: 9672656

Moller, P., L.E. Knudsen, S. Loft and H. Wallin, 2000. The comet assay as a rapid test in biomonitoring occupational exposure to DNAdamaging agents and effect of confounding factors. Cancer Epidemiol. Biomarkers, Prev., 9: 1005-1015. PMID: 11045781

Ostling, O. and K. Johanson, 1984. Microelectrophoretic study of radiation-induced DNA damages in individual mammalian cells. Biochem. Biophys. Res. Commun., 123: 291-298. PMID: 6477583

Padrangi, R., M. Petras, S. Ralph and M. Vrzoc, 1995. Alkaline single cell gel (comet) assay and genotoxicity monitoring using bullheads and carp. Environ. Mol. Mutagen., 26: 345-356. PMID: 8575424

Rigonato, J., M.S. Mantovani and B.Q. Jordao, 2005. Comet assay comparison of different corbicula fluminea tissues for the detection of genotoxicity. Genet. Mol. Biol., 28: 464-468. DOI: 10.1590/S1415-47572005000300023

Rojas, E., M.C. Lopez and M. Valverde, 1999. Single cell gel electrophoresis assay: Methodology and applications. J. Chromatogr. B Biomed. Sci. Appl., 722: 225-254. PMID: 10068143

Souza, T.S. and C.S Fontanetti, 2007. Ensaio do cometa para avaliacao das aguas do rio Paraiba do Sul, numa area sob influencia de uma refinaria de petroleo. Campinas, 62: 1-10. 
Singh, N.P., M.T. Mccoy, R.R. Tice and E.L.
Schneider, 1988 A simple technique for Schneider, 1988. A simple technique for individual cells. Exp. Cell Res., 175: 184-191. PMID: 3345800
Villela, I.V., I.M. Oliveira, J. Silva and J.A.P. Henriques, 2006. DNA damage and repair in haemolymph cells of golden mussel (Limnoperna fortunei) exposed to environmental contaminants. Mutat. Res. Genet. Toxicol. Environ Mutagen., 605: 78-86. PMID: 16697250 